\title{
The Character Values of Hard Work in the Novels of Leila S. Chudori
}

\author{
Renita Br Saragih ${ }^{1}$, Sahid Teguh Widodo ${ }^{1}$, Nugraheni Eko Wardani ${ }^{1}$ \\ ${ }^{1}$ Postgraduate of Sebelas Maret University, Surakarta, Indonesia \\ renitasaragih1009@gmail.com
}

\begin{abstract}
Literary works are a media that has an important role in building character. One of the literary works is novels. A novel contributes the thoughts and ideas of the author through the language that aims to provide benefits to the readers. This study aimed to describe the character values of hard work in the novels of Leila $S$. Chudori. This was a qualitative research using descriptive qualitative method and content analysis. The data in this research were from the novels of Leila S. Chudori. The research results showed that the character values of hard work of the character were found through the implied words, phrases, and sentences in the novels of Leila S. Chudori. The character values of hard work in the novels could be seen from how the character was persistent to achieve the goals, and able to find solutions for every problem. The characters of hard work reflected from the character could provide a value or message for the readers of the novels of Leila S. Chudori. The characters of hard work found in the two novels were: (1)unyielding attitude, (2) willingness to try, (3) living a life with positive thinking, and (4) character of struggling for life.
\end{abstract}

Keywords : character education; hard work; novel

\section{Introduction}

Character education is an essential necessity in the era of technology and information that has penetrated the cultural boundaries between nations. The swift flow of change has eroded the joints of the people's lives, especially the younger generation, including students. The impact caused by this change is an alteration of the moral ethical values that are far from the national cultural values. The negative impact that arises is the instant perspective and thinking.

The character building in a child is influenced by the environment. If the child lives in the character social environment, he will have good characters. The students who have good characters will be able to improve the academic achievement (Benninga, et al., 2003) and the soft skill (Mustari, 2014). If a person has good characters, he will not only have the good academic achievement and soft skill, but also the positive mentality. The healthy positive mentality will not only provide benefits to himself, but also to his surrounding environment (Ryan \& Deci, 2000). In addition, according to a research, Hokanson (2013: 107) showed that the strength of character or non-cognitive skill has more influences to a person's career and future than his cognitive skill. Therefore, it is necessary to have strong skill and willingness from various parties to develop the strengthening of the values of character education.

Success and failure of a nation are very dependent on the efforts of fostering and developing the characters of the people. Character education aims to foster students to be good individuals. Indonesian government through the Ministry of Education and Culture divides the values of character education into 18 categories that become references to be implemented by educational institutions in Indonesia. One of the values of character education is the value of character education of hard work. Hard work is the form of a person's persistence in the effort of obtaining what to be achieved. 
Character education can be taught through several ways. One of them is literary works. Literary works can provide benefits for the author and the readers. The author can express all the feelings, ideas, and concepts of the noble values, beliefs, and aesthetic values which then he conveys into literary works. Nurgiyantoro (2013: 434) stated that literature has a role as one of the educational tools that should be used in the educational world. Literature can be focused to the role of building the students' characters. This in line with a research of Kusuma (2018). Kusuma stated that moral behaviors in a novel can be a solution to overcome moral degradation of a nation.

Novel is one of the forms of literary works that contains a social representation created by the author in accordance with his perspective and social environment that provides the meaning of life in the form of moral values. Bohlin (2005: 18-19) stated that a good author is not only a good storyteller, but also a great psychological portrait painter. His character life also provides access to the readers to his personal world to motivate every individual. Character values in the novel can be learning materials of character values to the students. The novels of Pulang and Laut Bercerita by Leila S. Chudori are literary works that contain the life struggle during the reign of Indonesian President of Suharto and provide the values of character education. The objective of this research was to describe the character of hard work in the novels of Leila S. Chudori entitling Pulang and Laut Bercerita.

\section{Literature Review}

Literary works are the reflections of feelings, experiences, and thoughts of the author in the relation to life. Nurgiyantoro (2013: 2) conveyed that a literary work or writing fiction is a process of interpreting life. Novel is a part of the literary work. Altenbernd \& Lewis (1966: 14) defined a novel as an imaginative narrative prose, but it is still rational and contains truth.

Waluyo (2011: 36) explained that a novel is the symbol of new art based on the facts and experiences of the author. The composition described in the novel is realistic and rational. The described life refers to the strengths and weaknesses of the characters that also show the values that are able to teach good and noble characters. Based on those explanations, a novel can be defined as a part of the work that describes or reflects a life and real behaviors and contains the values that can be taught to the readers.

Character (karakter in Indonesian language) comes from Greek, karaso, which means blueprint, basic format, fingerprint. Pala (2011: 24) conveyed thatcharacter is characteristic or sign that distinguishes us from other people. Samani (2011: 42) defined character as characteristic that develops and distinguishes personal characteristics, ethical characteristics, and mental complexity of a person, group, or nation. Thus, it can be concluded that character is behavior and habit of a person regarding his identity, the way of thinking, and the way of life that distinguish him from other people. Lickona (2016: 82) stated that good characters consist of knowing, wanting, and doing good things. To produce a generation that has good characters, character education is needed.

The character of hard work is one of the categories that is taught in the character education. It is a behavior that shows the earnest effort to overcome various learning and task obstacles and finish the tasks as well as possible. Elfinfri, et al. (2012: 102) explained that the character of hard work is the characteristic of a person that is not easy to give up and has willpower in the efforts of achieving his goals and ambitions. Hidayatullah (2010: 29) 
expressed hard work as the ability to devote or exert all of the efforts, sincerity, and the possessed potential until the end of a business period in which the goal is achieved.

\section{Research Methodology}

This study aimed to describe and explain the character values of hard work in the novels of Pulang and Laut Bercerita by Leila S. Chudori. This was a type of descriptive qualitative research with content analysis. Qualitative research is a research that produces descriptive data in the terms of written or spoken words by the people or the observed behaviors (Moeleong, 2017: 5). The data sources in this research were the novels of Leila S. Chudori entitling Pulang, which was published in 2016 as the seventh print by the Popular Literature Publisher of Gramedia with 468 pages, and LautBercerita, which was published in 2017 by the Popular Literature Publisher of Gramedia with 398 pages.

Collecting the data in this research used the techniques of reading, noting, and library. The reading technique is a technique used by a person or several informants to obtain the data. This technique is carried out by reading a novel repeatedly to obtain the accurate data. The noting technique is the advanced technique after implementing the reading technique (Mahsun, 2005: 29). This technique is carried out by taking notes of the important parts. The next is the library technique. This is a technique that uses the written sources to obtain the data.

\section{Result \& Discussion}

Leila S. Chudori is an Indonesian writer that has written several literary works, such as, short stories, short story collections, and novels. Leila began her writing career since she was 12 years old. As a writer, Leila received an award as the Scenario Writer of the Praised Television Drama, FFB 2007 (for the scenario of “Dunia Tanpa Koma”).In 2011, she received a Literature Award of Indonesian Language Agency for her book entitling 9 dari Nadira. Leila began to write novels entitling Pulang in 2012 and Laut Bercerita in 2017.

The novel of Pulang tells the readers about the life of a political exile named Dimas Suryo. This novel tells them about the life of Dimas Suryo in Paris. When the student revolution raged in Paris, Dimas Suryo, an Indonesian political exile, met Vivienne Deveraux, a French student who took part in a demonstration against the French government. At the same time, Dimas received news from Jakarta: HanantoPrawiro, his best friend, was arrested by the army. Dimas felt anxious and afraid. With dozens of journalists and other artists, he could not return to Jakarta because his passport was revoked by the Indonesian government. Since then, they have wandered without clear status from Santiago to Havana, to Peking and finally, landed in Europe to get home and stay there.

After the incident, Dimas married Vivienne Deveraux and had a child named Lintang Utara.The past life of Dimas was the trigger for his divorce with Vivienne Deveraux because Dimas kept remembering his past. After getting divorced, Dimas and his friends established a restaurant. In the midst of being busy of managing an Indonesian Restaurant in Paris with his three friends: Nug, Tjai, and Risjaf, Dimas and his friends were called the Four Pillars of the Motherland. Dimas was constantly chased with guilt because his friends in Indonesia, one by one collapsed, were chased, shot, or disappeared in the hunt in the September $30^{\text {th }}$ incident.

In May 1998, Dimas Surya's daughter,Lintang, with Vivienne Deveraux, finally managed to obtain an Indonesian visa to record the experiences of the families of the victims 
in the September $30^{\text {th }}$ tragedy as her final assignment. With Segara Alam, Hananto's son, Lintang witnessed the biggest riots in Indonesian history. The May 1998 riots were the story of the fall of the government throne of President Suharto that had been in power for 32 years. The end of this story was the passing of Dimas Suryo in a cage confinement after a tiring long struggle for more than 33 years wandering in the foreign country and being wasted. Dimas' return was accompanied by tears by his family and friends even though in truth, the spirit of Dimas smiled proudly because he finally returned to Karet, the last port and the resting placethat he really wanted.

The novel of Laut Bercerita tells the readers about the life of Biru Laut Wibisono as a literature student at Gajah Mada University who joined an organization of Wirasena to carry out the forbidden activities according to the government. This novels tells them about the activities of Biru Laut as a student and an activist, the relationship of Biru Laut and his friends, and the attraction process of Biru Laut to a girl named Anjani. The story of Biru Laut began with his friendship story with Alex, Sunu, Daniel, Julius, Gusti, Bram, Kinan, and other activists.

In the Chapter of Seyagan, Laut tells the readers about his meeting with friends who had the same interest. The interest was to undermine the injustices committed by the government regime at that time. Even though they knew, enforced disappearance was a risk that might occur to them or a slogan of "shooting on the spot" would approach their lives. After meeting with the people who had the same goal, Biru Laut and friends took an action of planting corn. Actions of Wirasena made the Government oversee the activities of the organization until BiruLaut had to hide and could not communicate with his family.

On March 1998, it was the turn of the Wirasena activists that were kidnapped, tortured, and inhumanely interrogated. Laut, Sunu, Kinan, Bram, the poets, and some friends disappeared without a trace after being held captive. At this confinementBiruLaut experienced a barrage of torture and disappeared somewhere. They, namely Alex, Daniel, Naratama, Coki, Hamdan, and the other five persons were returned alive. On the other hand, the others disappeared without news. When the regime collapsed in May 1998, they began to be able to speak out for the atrocities they received.

The story then continued from the point of view of Asmara Jati, the sister of BiruLautWibisono and the lover of Alex Perazon. As a family that was abandoned mysteriously by the older brother, they were very lost. The story of Asmara began in the 2000s. Along with the family of other activists, Asmara joined Aswin and tried to look for justice to the government. The sorrow made many families living in denial. They lived in an imagination in which their lost family still lived in everyday life.

Their father still prepared four dishes in the ritual dinner together on Sundays. The family played the songs that marked the presence of Laut and cleaned the books and the room of Laut as if Laut would suddenly come. All the left families tried to entertain one another even though they could not accept the possibility if their child, lover, husband were gone.

In the two novels of Leila S. Chudori entitling Pulang and Laut Bercerita, the research results showed that there were the character values of hard work contained in the novels.

\section{1 The Characters of Hard Work of Dimas Surya in the Novel of Pulang}

Dimas Surya was a person who was exiled from his home country and lived in another country. The story of Dimas began in a place of exile. He was rejected by his home country to 
return. Dimas Surya was a person who had the power of struggle to survive in another country and the strong desire to return to his home country. The story of Dimas started from the arrival of Dimas to the conference of International Organization of Journalist in Santiago. After attending the conference, Dimas could not return to Indonesia because of the September $30^{\text {th }}$ incident. After the incident, Dimas and friends decided to go to Peking. When he was in Peking, Dimas decided to look for a job and was not dependent to his friends in Peking. This can be seen in the following quotation.

"We don't care what kind of job that we must do, the important thing is to be able to earn a living." (Chudori, 2016: 73)

That quotation shows that Dimas did not care what kind of job that he must do as long as he could maintain his life. Whatever the job was, Dimas would do it to survive. Dimas' goal was to earn money and he tried to achieve his goal.

Beside earning a living, Dimas also tried to add his French vocabularies with the aim of being able to live a new life in another country.

"at the beginning, my brain dictionary only consisted of the words of ouior non or cava. Because Viviane forced to add 10 French vocabularies to my vocabulary cabinet every day, I started to learn this beautiful language seriously." (Chudori, 2016: 18)

Living a life in the foreign country was not easy. The character of Dimas reflected that life would be easy when we wanted to try and made every effort to live what we were going through although it seemed difficult.

After getting divorced with Viviane, Dimas still had the character of hard work in his life. His divorce with Vivian did not make him slumped and give up living his life in France. Dimas established an Indonesian restaurant with his friends. He started his business by compiling the menu that would be included in the proposal. The proposal was the first step of Dimas and friends to obtain the fund. Dimas did not stop at that step. He tried to make various food recipes by modifying them. This is in line with the following quotation.

"We designed the opening day in December. As the day was closer, I struggled in the kitchen with Bahrum and Yazir. The recipes were tried, played, made variations and modifications for the parties or just a small celebration. Two weeks before the opening of the restaurant, in the days and nights, we began experimenting with various recipes to make an impression that was attached to the visitors." (Chudori, 2016: 112)

From the above quotation, it can be seen that the character of hard work of Dimas made every effort to create the food menu that was suitable and liked by his customers. Because of his hard work, all the efforts made by Dimas in the earnest for the success of his restaurant paid off. The restaurant was in demand by the French people. This can be seen in the following quotation.

"Maman has been busy pacing to help Om Nugand me because in December, Restoran Tanah Air is always full." (Chudori, 2016: 140)

The character of hard work of Dimas could also be seen in achieving his greatest desire, to return home to Indonesia. There was nothing that could hinder his greatest desire. Dimas did various ways to achieve his desire. This can be found in the following quotation.

"I routinely tried to apply for a visa to enter Indonesia." (Chudori, 2016: 195-196) 
Dimas got rejection for unclear reasons. He kept trying and did not give up to survive in the existing situation. Until the end of his life, Dimas did not give up and always tried to achieve what he wanted to the extent of his ability. Dimas struggled tirelessly despite finally giving up. This can be seen in the following quotation.

"The graveyard in Paris is indeed extraordinary. It was built not only for the desire to continue the relationship with those who had already 'crossed' in the place they cannot know, but also at the same time to maintain melancholy. But, I think, I will be happier if I can be buried in Karet. One house with Chairil Anwar." (Chudori, 2016: 274-275)

Dimas' great desire, the efforts he did, and his unyielding attitude remained a part of himself that deserves to be imitated. Dimas still tried to return home even though he was already lifeless. During his lifetime, Dimas made various efforts to survive and return to Indonesia, and at the end of his life, Dimas could realize his desire. This is an unyielding character that deserves to be imitated even though there were many challenges, Dimas survived and his desire finally came true.

\subsection{The Character of Hard Work of Biru Laut in the Novel of Laut Bercerita}

Biru Laut was a student of English literature Faculty and also an activist. He had the character of hard work in his life. He was the main character in which his life was dedicated to help other people. The conflicts in Laut's neighborhood made him try and make every effort towards what he was doing. Laut was an activist that tried to fight for justice in his country.

"...they are proud of Laut who wants to change the country to become better even though it is from the small things, like accompanying the farmers or holdingthe workshops on labor rights in Jakarta." (Chudori, 2017: 289)

"we don't have any bayonet gun; we don't have muscle, we don't have money. Our movement is based on enthusiasm, personal money, and the contribution of some individuals who are fed up with the new order government which is increasingly repressive from year to year. This time, we add the resistance weapon with the poem and the action of planting corn." (Chudori, 2017: 116-117)

Those quotations shows that Laut started something from the small things. He started the struggle by accompanying the farmers and using the poem in the action of fighting for justice. Laut started his struggle from the lowest step. As the main character, he did not see his weaknesses. Laut used what he had and tried to add some actions.

"...the action of Ngawi was considered successful, so long before we had ever learned from the failure of 'Kwangju discussion'.” (Chudori, 2017: 112-113)

Laut experienced many obstacles to achieve his goals, but it did not change Laut's principle, and he tried to rise from the failure. The following quotations describe Laut's difficult situations. He had to move to different cities, but he had the unyielding and optimistic attitude. Laut enjoyed every process that he was going through. He always tried to keep trying and focused on the positive things.

“...a year we kept moving, to Bogor, Cilegon, Bekasi, and we had ever moved to Bandung to return to West Jakarta." (Chudori, 2017: 211)

"between the crouching life, it doesn't mean we just sit quietly." (Chudori, 2017: 212)

"...this is all for the money they have given before we are declared fugitive and I still have to do my job.” (Chudori, 2017: 206) 
The following quotations describe the character of Laut who thought positively towards what he was going through.

"a week in Lampung, a week in Pekanbaru, and now in Padang sometimes do not make us feel like fugitives." (Chudori, 2017: 205)

"what can we do about it? Sumatran food in any part is really amazing, don't be surprised if sometimes we forget we aren't on vacation." (Chudori, 2017: 205)

"...actually we simply enjoy a good eating situation and are isolated from Jakarta news." (Chudori, 2017: 205)

From those three quotations, it can be seen that Biru Laut felt happy even though he was on fugitive. This was because the character of Laut who thought positively so that it did not disturb his mind and make him tremble.

There were the values of character education of hard work contained in the novels of Pulang and Laut Bercerita. The values of character education of hard work found in those two novels were unyielding attitude, willingness to try, living a life with positive thinking, and character of struggling for life.

\section{Conclusion}

Based on the research results, hard work is the earnest effort carried out by a person to achieve his goals although there are some obstacles. The character of hard work in those novels describes the optimistic attitude of the characters. The values of hard work in the novels of Pulang and Laut Bercerita by Leila S. Chudori consist of unyielding attitude, willingness to try, living a life with positive thinking, and character of struggling for life.

\section{References}

Altenbernd, L. \& Lewis, L.L. (1996). A Handbook for the Study of Fiction. London: The Macmillam Company.

Benninga,J. S., Berkowitz, M. W., Kuehn, P., \& Smith, K. (2003). The Relationship of Character Education Implementation and Academic Achievement in Elementary Schools. Journal of Research in Character Education, 1(1), 19-32.

Bohlin, E. K. (2005). Teaching Character Education Through Literature: Awakening theMoral Imagination in Secondary Classrooms Teaching Character Education. New York: Routledge Taylor \& Francis Group.

Chudori, L.S. (2016). Pulang. Jakarta: KPG (Kepustakaan Popular Gramedia).

Chudori, L.S. (2017). Laut Bercerita. Jakarta: KPG (Kepustakaan Popular Gramedia).

Elfindri, L. H., Wello, M. B.,Hendmaidi, E. E.,\& Indra.R. (2012). Pendidikan Karakter: Kerangka, Metode dan Aplikasi untuk Pendidik dan Professional. Jakarta: Badause Media.

Hidayatullah, M. F. (2010). Pendidikan Karakter: Membangun Peradabaan Bangsa. Surakarta: Yuma Pustaka.

Hokason, B., \& Roger, W. K. (2013). Borderlands: Developing Character Strengths for a Knowmadic World. On The Horizon, 21(2), 107-113.

Kusuma, K. A., Waluyo, H. J., \& Wardani, N. E. (2018). Indonesian Literature as National Character Builders. The $1^{\text {st }}$ Internasional Confrence on Education Language and Literature (ICON-ELITE) 2018 Proceeding, 53-60. 
Lickona, T. (2016). Persoalan Karakter: Bagaimana Membantu Anak Mengembangkan Penilain yang Baik, Intergritas, dan Kebijakan Penting Lainnya. Jakarta: Bumi Aksara.

Mahsun. (2005). Metodologi Penelitian Bahasa. Jakarta: PT Raja Grafindo Persada.

Moleolong, L. J. (2017). Metodologi Penelitian Kualitatif. Bandung: Remaja Rosdakarya.

Mustari, M. (2004). Nilai Karakter Refleksi untuk Pendidikan. Jakarta: PT. Raja Grafindo Persada.

Nurgiyantoro, B. (2013) Teori Pengkajian Fiksi. Yogyakarta:Gajah Mada University Press.

Pala, A. (2011). The Need for Character Education. Internasional of Social Sciences and Humanity Studie, 3(2), 23-32.

Ryan, R. M., \& Deci, E. L. (2000). Self- Determination Theory and the Facilitation of Intrinsic Motivation, Social Development, and Well-Being. American Psychologist, 55(1), 68-78.

Samani, M., \& Hariyanto. (2011),. Konsep dan Model Pendidikan Karakter. Bandung: Remaja Rosdakarya.

Waluyo, H.J. (2011). Pengkajian dan Apresiasi Prosa Fiksi. Surakarta: UNS Press. 